\title{
РЕЗУЛЬТАТИ ОПИТУВАННЯ СТУДЕНТСЬКОЇ МОЛОДІ НАВЧАЛЬНИХ ЗАКЛАДІВ ВИЩОЇ ОСВІТИ М. ТЕРНОПІЛЬ ЩОДО УРАЖЕННЯ ЇХ ІКСОДОВИМИ КЛІЩАМИ
}

\author{
ФС. С. Подобівський, Л. Я. Федонюк, Л. О. Шевчик'
}

Тернопільський національний медичний університет імені І. Я. Горбачевського МОз України

${ }^{1}$ Тернопільський національний педагогічний університет імені Володимира Гнатюка

РЕЗЮМЕ. Проведено опитування 278 студентів ТНМУ імені І. Я. Горбачевського МОЗ України та ТНПУ імені В. Гнатюка. Більшість учасників анкетування зазнали нападів іксодових кліщів у різних біотопах. Близько 14 \% респондентів зверталися до спеціалізованих лабораторій для аналізу крові на виявлення збудників інфекційних захворювань або антигенів до цих збудників. У 10 респондентів було діагностовано бореліоз.

Мета - дослідити особливості ураження кліщами студентів, виходячи з місця їх проживання, частоти відвідування ними небезпечних щодо активності кліщів біотопів та проаналізувати поведінку осіб, уражених кліщами, їх звернення до лікарів, знання про біологію кліщів та особливості поширення збудників кліщових інфекцій.

Матеріал і методи. Було надіслано 374 онлайн-анкети і отримано 278 відповідей від студентів двох навчальних закладів м. Тернопіль.

Результати й обговорення. Встановлено, що більше 63 \% анкетованих осіб постійно проживають у міській місцевості, близько 60 \% опитаних зрідка або майже не бувають у місцях із підвищеною активністю кліщів, проте понад 80 \% їх піддавалися неодноразовим укусам кліщів. Це явно вказує на те, що іксодові кліщі активні не лише в природних біоценозах, але і в урбоценозах. 3 уражених кліщами студентів лише 14 \% зверталися до спеціалізованих лабораторій. 10 студентам було поставлено діагноз бореліоз.

Висновок. Понад 66 \% опитаних респондентів мешкають у великих і малих містах, селищах міського типу, проте близько 80 \% опитаних фіксували напади на них кліщів з різною частотою, чому, очевидно, сприяло їх відвідування парків, скверів, садів тощо; лише 14 \% уражених кліщами зверталися у спеціалізовані лабораторії на предмет виявлення збудників інфекційних захворювань у крові, у майже 2 \% ці результати були позитивними і було встановлено діагноз бореліоз; близько 25 \% респондентів мало знають про бореліоз, а понад 33 \% не могли відповісти на запитання «Які організми зумовлюють бореліоз?», ще близько 40 \% - не знали збудників хвороб, окрім бореліозів, які переносять іксодові кліщі.

КлючОВІ СлОВА: анкетування; студенти; іксодові кліщі; діагностика; бореліоз.

Вступ. Іксодові кліщі - один із біологічних факторів, який негативно впливає на здоров'я населення Європи, Азії та Північної Америки. За останні 10 років частота нападів іксодових кліщів на людей у цих регіонах невпинно зростає. Україна, як європейська країна з помірним кліматом, за цей період також відчула це зростання [1]. Проте, активні дослідження іксодових кліщів у державі розпочалися не так давно. Починаючи з 2000 року в Україні загалом та по областях окремо ці дослідження починались переважно на базі біологічних факультетів університетів та медичних закладів вищої освіти. Напади кліщів починають фіксуватися у травмпунктах лікарень, а обмеженням чисельності цих членистоногих займаються санітарно-епідеміологічні станції та лабораторії у великих містах.

Мета - дослідити особливості ураження кліщами студентів, виходячи з місця проживання учасників анкетування, частоти їх відвідування небезпечних щодо активності кліщів біотопів та проаналізувати поведінку осіб, уражених кліщами, їх звернення до лікарів, знання про біологію кліщів та особливості поширення збудників кліщових інфекцій.

Матеріал і методи. Було надіслано 374 онлайн-анкети і отримано 278 відповідей від студен- тів двох навчальних закладів м Тернопіль: Тернопільського національного медичного університету імені І. Я. Горбачевського МОЗ України та Тернопільського національного педагогічного університету імені Володимира Гнатюка.

Результати й обговорення. У Тернопільському національному медичному університеті імені І. Я. Горбачевського МОЗ України (ТНМУ) перші праці з дослідження кліщових інфекцій з'явилися вже у 2013 році [2, 3]. у 2017 році була створена спеціалізована лабораторія з дослідження кліщів та кліщових інфекцій при університеті, де почали досліджувати особливості морфології кліщів на різних стадіях розвитку, їх епідеміологічний стан, фізіологію живлення тощо. Основним матеріалом для дослідження були кліщі, зняті з людей у травмпунктах Тернопільської обласної лікарні та Тернопільської обласної дитячої лікарні. Досліджувалися також і кліщі, зняті з тварин студентами-волонтерами, які підключилися до цієї роботи.

Аналіз літературних джерел, які висвітлюють багато аспектів дослідження кліщів і кліщових інфекцій у Європі, не показав фактів вивчення нападів кліщів окремо на певні вікові категорії людей: дітей, учнівську чи студентську молодь тощо. 
Огляди літератури, оригінальні дослідження, погляд на проблему, випадок з практики, короткі повідомлення

В лабораторії ТНМУ здійснюють аналіз закономірностей нападів кліщів на певні категорії населення за фахом: лісники, сільськогосподарські працівники, пенсіонери і т. п. Також проведено аналізи закономірностей нападів кліщів на дітей різного віку $[4,5]$. У 2017 році було проведене первинне опитування студентської молоді ТНМУ на предмет ураження їх іксодовими кліщами. Було опитано 775 студентів, з яких 319 (40,4%) зазнали нападів кліщів. Цікавим фактором було те, що серед уражених кліщами студентів близько 55 \% були мешканцями міст, і кліщі нападали на них безпосередньо за місцем проживання, в зелених рекреаційних зонах. У 29 студентів з'являлася еритема або подібне на еритему почервоніння. На той час лише декілька осіб зверталися до спеціалізованих лабораторій на предмет дослідження кліщів і крові на наявність збудників інфекційних захворювань. Одному студенту було діагностовано бореліоз.

Повторне опитування студентської молоді було проведено у 2021 році. Цього разу було розіслано онлайн-анкети студентам двох закладів вищої освіти м. Тернопіль: ТНМУ та Тернопільський національний педагогічний університет імені Володимира Гнатюка (ТНПУ). Відповіді було отримано від 278 студентів, з них 258 студентів ТНМУ і 30 студентів ТНПУ.

Більшість відповідей було отримано від осіб жіночої статі (194 особи, що склало 70,8 \%). Серед опитаних переважали студенти першого курсу (180 осіб, що склало 65,7 \%), 60 осі6 (21,9 \%) - студенти 2 курсу, 21 особа (7,7 \%) - студенти 3 курсу і 17 осіб (4,7 \%) були студентами 4 і 5 курсів.

Більше половини опитаних студентів $(50,4 \%)$ постійно проживають в містах, третина ( 33,6 \%) - в сільській місцевості і $16 \%$-у селищах міського типу.

Більше половини студентів (46,4 і 9,5 \%) зрідка або майже не бувають в місцях, де на них можуть нападати кліщі, а 34,3 \% та 9,8 \% відповідно в цих місцях бувають часто і дуже часто.

174 респонденти, що складає 63,5 \%, зазначили, що кліщі їх кусали 1-2 рази, 33 опитаних (12 \%) кліщі кусали більше 2 разів. 16 респондентів, що складає 5,8 \%, відзначили, що їх кліщі кусали регулярно 1-2 рази за сезон, 51 студент (18,7 \%) ніколи не помічав укусів кліщів.

Аналіз біотопів, де кліщі активно нападали на людей, показав, що найчастіше це відбувалося в лісі ((167 осіб, що становить 60,9 \%), в парковій зоні (29 осіб, що складає 10,6 \%), в саду (26 осіб, $9,5 \%)$, на лузі (15 осі6, 5,5 \%). Решта респондентів, що складає 13,5 \%, або не знають де відбувся укус, або їх кліщ не кусав.

208 респондентів, що становить 75,9 \%, виявили на собі кліща вже через кілька годин, 47 осіб, що складає 17,4 \%, виявили на собі кліща на другий день, а решта - через два і більше днів. Лише 89 студентів (32,5 \%) планомірно оглядали себе і виявили кліщів після виходу із зеленої зони, 127 осіб (46,4 \%) виявили на собі кліщів випадково, а решта студентів, що склало 11,1 \% виявили на собі кліщів лише тоді, коли відчули біль і свербіння в місці прикріплення кліща.

Близько 58,3 \% укушених осіб видалили кліща протягом 12 годин, 9,4 \% опитуваних видалили кліща протягом доби, ще 6,1 \% - протягом 2 діб, а близько $18 \%$ респондентів точно не знали, коли до них вчепився кліщ і протягом якого часу вони його видалили, ще 8,2 \% респондентів не фіксували кліщів на тілі, але в них проявлялися незвичні симптоми, які вони пов'язали з можливими укусами цих членистоногих.

Лише близько 21 \% опитуваних (59 осіб) зверталися до лікарів спеціалізованих медичних закладів для видалення кліща. Решта респондентів витягали кліщів самостійно або за участі друзів і родичів.

При видаленні кліща 14 \% респондентів заливали кліща олією, а 3,6 \% - дезінфікуючим розчином, понад 60 \% витягали кліщів пінцетом, ниткою або просто пальцями, решта - іншим способом (голкою, булавкою тощо).

3 усіх респондентів понад 86 \% ніколи не робили аналіз крові на предмет виявлення в ній антитіл до збудників кліщових інфекцій. Близько $14 \%$ опитаних такі аналізи робили і лише у 4 осіб, що складає 1,5 \%, було отримано позитивний результат.

Близько 90 \% учасників анкетування ніколи не помічали на тілі мігруючої еритеми. Проте, у понад $10 \%$ опитаних з'являлася еритема або ознаки, подібні на неї. 3 них у 8 \% (22 особи) червона пляма з'являлась на місці укусу, а у 2,2 \% (6 осіб) - у місці, віддаленому від укусу кліща.

Серед тих студентів, які зауважили появу еритеми або плями, подібної на еритему, більшість не пам'ятає, на який день після укусу кліща вона з'явилася. Близько 6,5 \% опитуваних стверджують, що еритема виникла від 24 до 48 годин. У 1,5 \% вона з'явилася через 3 дні, у 1,1 \% - через 7 днів, у 0,4 \% - через 14 днів, а у 0,7\% - через 30 днів після укусу кліща. Можливо, що справжня еритема була у 2,2 \% опитаних і з'явилася в них у період від 7 до 30 днів.

12 студентів, що складає 4,4 \%, відчули незвичні симптоми через якийсь час після укусів кліщів.

Серед тих студентів, які відчули незвичні симптоми, у більшості (56,7 \%) відмічалися біль і запалення суглобів, у частини підвищувалася температура, збільшувалися лімфатичні вузли і був встановлений діагноз ураження лицевого 
Огляди літератури, оригінальні дослідження, погляд на проблему, випадок з практики, короткі повідомлення нерва. Деякі з них вказували на послаблення концентрації уваги.

13,5 \% (37 респондентів) у цей період зверталися до лікарів, проте з них лише 12 студентів, що складає 4,4 \%, зверталися з приводу вищевказаних симптомів, а 25 (9,1\%) - з інших причин.

13 студентів звернулися до лікарів відразу після появи симптомів, а 9 - через кілька днів, решта не змогли точно відповісти на це питання.

10 студентам був встановлений діагноз - 6ореліоз, що, порівняно з 2017 роком, більше у 10 разів. Усі вони отримали лікування з приводу бореліозу.

12 студентам було встановлені діагнози ураження опорно-рухової, серцево-судинної, нервової систем та проблем зі шкірою, які, можливо, пов'язані з бореліозом. 33 студенти перебували під наглядом кардіолога, невропатолога, дерматолога чи іншого спеціаліста.

Серед препаратів, призначених для лікування, переважали антибіотики, препарати, що впливають на центральну і периферичну нервову систему, препарати, що впливають на серцево-судинну систему і згортання крові, антигістамінні та сечогінні препарати.

За результатами опитування встановлено, що лише 18,6 \% респондентів мають достатньо знань про бореліоз, 55,8 \% знають про цю хворобу дуже мало, а 25,6 \% взагалі нічого не знають про цю хворобу.

Близько 30 \% опитаних знають про збудників кліщових інфекцій зі школи, понад 25 \% отримали ці знання у навчальному закладі вищої освіти, понад 16 \% взяли відомості з інтернет-ресурсів, а решта з інших джерел.

Лише близько 38 \% респондентів знають, що збудниками бореліозів є бактерії, більше 33 \% взагалі нічого не знають про походження збудників, понад 25 \% вважають, що збудниками боре-

\section{ЛІТЕРАТУРА}

1. Подобівський С. С. До питання видового складу, біології та значення іксодових кліщів Західної України / С. С. Подобівський, Л. Я. Федонюк, О.О.Лобода // Наукові записки Тернопільського національного педагогічного університету ім. Володимира Гнатюка. Сер. Біологія. - № 2(69). - 2017. - С. 123-129.

2. Епідеміологічна характеристика, особливості клінічного перебігу та діагностики системного кліщового бореліозу в Тернопільській області / Л. Я. Федонюк, Г. П. Чабан, Л. Н. Рибіцька, О. С. Авсюкевич // Таврический медико-биологический вестник. - 2013. № $16(1,4.2)$. - С. 198-202.

ліозів $\epsilon$ мікроорганізми тваринного походження, а понад $3 \%$ - віруси. Близько 40 \% нічого не знають про інших збудників інфекцій, що переносяться кліщами.

Висновки. 1. Як показали результати анкетування, більше половини опитаних респондентів (понад 63 \%) є мешканцями великих і малих міст та селищ міського типу. Проте близько 80 \% опитаних фіксували напади на них кліщів з різною частотою, чому, очевидно, сприяло їх відвідування місць (понад 80 \%), де $\epsilon$ небезпека наразитися на кліщів.

2. Негативним фактом $є$ те, що близько $20 \%$ місць, де проявляється активність кліщів, $є$ парки, сквери, сади, зелені прибудинкові насадження в різних населених пунктах.

3. Викликає тривогу той факт, що лише близько 30 \% респондентів планомірно оглядали себе після виходу із зелених зон, насичених кліщами. ще понад 50 \% виявляли кліщів випадково або лише тоді, коли відчували біль в ураженому місці. Тому в понад 30 \% молодих людей кліщі живилися кров'ю більше 12 годин, що спричиняє ризик передачі кліщем у кров людини збудників інфекційних захворювань.

4. Встановлено, що лише 14 \% молодих людей, які піддавалися укусам кліщів, зверталися у спеціалізовані лабораторії для дослідження на предмет виявлення збудників інфекційних захворювань у крові. У майже 2 \% ці результати були позитивними і було поставлено діагноз бореліоз та призначено відповідне лікування.

5. Негативним результатом опитування $\epsilon$ те, що близько 25 \% респондентів майже нічого не знають про бореліоз, а понад 33 \% не могли правильно відповісти які організми зумовлюють це захворюваня, а близько 40 \% не знали, яких ще збудників хвороб, окрім бореліозів, переносять іксодові кліщі.

3. Федонюк Л. Я. Клініко-епідеміологічна характеристика Лайм-бореліозу в Тернопільській області / Л. Я. Федонюк, А. В. Довбуш, М.М.Багрій // Буковинський медичний вісник. - 2013. - № 17 (1). - С. 194-198.

4. Lyme borreliosis is an endemic disease in children of Ternopil region / S. Nykytyuk, S. Klymnyuk, S. Podobivsky, S. Levenets, O. Stelmakh // Georgian Medical News. - 2020. - Vol. 10 (307). - P. 95-106.

5. Tick bite - carriers of infectious diseases of children in ternopil region (Ukraine) S. O. Nykytyuk, S. I. Klymnyuk, S. S. Podobivskiy, L. Y. Fedoniuk, L. O. Shevchyk // East European Science Journal. - 2020. - Vol. 10(62). - P. 4-11. 
Огляди літератури, оригінальні дослідження, погляд на проблему, випадок з практики, короткі повідомлення REFERENCES

1. Podobivskyi, S.S., Fedoniuk, L.Ya., \& Loboda, O.O. (2017). Do pytannia vydovoho skladu, biolohii ta znachennia iksodovykh klishchiv Zakhidnoi Ukrainy [On the issue of species composition, biology and significance of the Ixodes ticks in Western Ukraine] Naukovi zapysky Ternopilskoho natsionalnoho pedahohichnoho universytetu im. Volodymyra Hnatiuka. Ser. Biolohiia - Scientific Issues Ternopil Volodymyr Hnatiuk National Pedagogical University. Series: Biology, 2(69), 123-129 [ in Ukrainian].

2. Fedoniuk, L.Ya., Chaban, H.P., Rybitska, L.N., \& Avsiukevych, O.S. (2013). Epidemiolohichna kharakterystyka, osoblyvosti klinichnoho perebihu ta diahnostyky systemnoho klishchovoho boreliozu v Ternopilskii oblasti [Epidemiological characteristic, clinical and diagnostic peculiarities of the systemic tick-borne Lyme in Ternopil region] Tavrycheskyi

medyko-byolohycheskyi vestnyk. - Tavrichesky Medical and Biological Bulletin, $16(1,2)$ 198-202 [ in Ukrainian].

3. Fedoniuk, L.Ya., Dovbush A.V., \& Bahrii M.M. (2013). Kliniko-epidemiolohichna kharakterystyka Laim-boreliozu v Ternopilskii oblasti [Clinico-epidemiological characteristic of lyme- borreliosis in the Ternopil region]. Bukovynskyi medychnyi visnyk - Buk. Med. Herald.,17 (1), 194-198 [in Ukrainian].

4. Nykytyuk, S., Klymnyuk, S., Podobivsky, S., Levenets, S., \& Stelmakh, O. (2020). Lyme borreliosis is an endemic disease in children of Ternopil region Georgian Medical News, 10 (307), 95-106.

5. Nykytyuk, S.O., Klymnyuk, S.I., Podobivskiy, S.S., Fedoniuk, L.Ya., \& Shevchyk, L.O. (2020). Tick bite-carriers of infectious diseases of children in ternopil region (Ukraine). East European Science Journal, 10(62), 4-11.

\title{
RESULTS OF THE STUDENTS' QUESTIONNAIRE OF HIGHER EDUCATION INSTITUTIONS OF TERNOPIL REGARD TO TICKS BITE
}

\author{
OS. S. Podobivskyi, L. Ya. Fedoniuk, L. O. Shevshyk ${ }^{1}$ \\ I. Horbachevsky Ternopil National Medical University \\ ${ }^{1}$ Volodymyr Hnatyuk Ternopil National Pedagogical University
}

SUMMARY. A survey of 278 students of 1-5 courses of I. Horbachevsky Ternopil National Medical University and Volodymyr Hnatyuk Ternopil National Pedagogical University was conducted. The results show that most of the participants in the survey were attacked by Ixodes mites in various anthropogenic and natural habitats. About $14 \%$ of respondents went to specialized laboratories for blood tests to detect pathogens of infectious diseases or antigens to these pathogens. 10 respondents were diagnosed with borreliosis.

The aim - to investigate the peculiarities of student mite infestation based on the place of residence of survey participants, the frequency of their visits to habitats dangerous to tick activity and to analyze the behavior of ticks affected, their treatment, knowledge of tick biology and the spread of tick-borne pathogens.

Material and Methods. 374 online questionnaires were sent and 278 responses were received from students of two educational institutions.

Results and Disscussion. According to the results of the survey, more than $63 \%$ of respondents live permanently in urban areas, about $60 \%$ of respondents rarely or almost do not visit places with high tick activity, but more than $80 \%$ of them have been repeatedly bitten by ticks. This clearly indicates that Ixodes mites are active not only in natural biocenoses, but also in urbocenoses. Among tick-infected students, only $14 \%$ sought specialized laboratories. 10 students were diagnosed with borreliosis.

Conclussions. More than $66 \%$ are residents of large and small towns and urban-type settlements, but about $80 \%$ of respondents show tick attacks with varying frequency, which was probably facilitated by their visitings of parks, squares, gardens, green house plantings; of the $14 \%$ of young people, who were bitten by ticks and approached specialized laboratories for testing for infectious diseases in the blood, almost $2 \%$ were positive and were diagnosed with borreliosis; about $25 \%$ of respondents know almost nothing about borreliosis, and more than $33 \%$ could not correctly answer the question "What organisms cause borreliosis?", another $40 \%$ - did not know pathogens other than borreliosis, which carry Ixodes mites.

KEY WORDS: questionnaire; students; Ixodes mites; diagnosis; borreliosis. 